\title{
Food choice, plate waste and nutrient intake of elementary- and middle-school students participating in the US National School Lunch Program
}

\author{
Stephanie L Smith* and Leslie Cunningham-Sabo \\ Department of Food Science and Human Nutrition, Colorado State University, 1571 Campus Delivery, \\ Fort Collins, CO 80523-1571, USA
}

Submitted 20 September 2012: Final revision received 29 May 2013: Accepted 13 June 2013: First published online 18 July 2013

\begin{abstract}
Objective: To (i) evaluate food choices and consumption patterns of elementaryand middle-school students who participate in the National School Lunch Program (NSLP) and (ii) compare students' average nutrient intake from lunch with NSLP standards.

Design: Plate waste from elementary- and middle-school students' lunch trays was measured in autumn 2010 using a previously validated digital photography method. Percentage waste was estimated to the nearest $10 \%$ for the entrée, canned fruit, fresh fruit, vegetable, grain and milk. Univariate ANOVA determined differences in percentage waste between schools, grades and genders. Daily nutrient intake was calculated using the district's menu analysis and percentage waste.

Setting: Elementary and middle schools in northern Colorado (USA).

Subjects: Students, grades 1-8.

Results: Plate waste was estimated from 899 lunch trays; 535 elementary- and 364 middle-school students. Only $45 \%$ of elementary- and 34\% middle-school students selected a vegetable. Elementary-school students wasted more than a third of grain, fruit and vegetable menu items. Middle-school students left nearly $50 \%$ of fresh fruit, $37 \%$ of canned fruit and nearly a third of vegetables unconsumed. Less than half of the students met the national meal standards for vitamins $\mathrm{A}$ and $\mathrm{C}$, or Fe.

Conclusions: Few students' lunch consumption met previous or new, strengthened NSLP lunch standards. Due to the relatively low intake of vegetables, intakes of vitamins $\mathrm{A}$ and $\mathrm{C}$ were of particular concern. Effective behavioural interventions, combined with marketing, communications and behavioural economics, will likely be necessary to encourage increased vegetable intake to meet the new meal standards.
\end{abstract}

\author{
Keywords \\ Food choice \\ Plate waste \\ Students \\ Nutrient intake \\ Meal recommendations
}

The overall health of children depends, in part, upon food intake that provides sufficient energy and nutrients to support optimal growth and development ${ }^{(1)}$. Yet diets consumed by most US children are not consistent with the Dietary Guidelines for Americans ${ }^{(2)}$. Children's consumption of fruits, vegetables, whole grains and low-fat and fat-free dairy are substantially less than current recommendations, resulting in shortfall intakes of several key nutrients, in particular $\mathrm{Ca}$, K, fibre, $\mathrm{Mg}$ and vitamin $\mathrm{E}^{(3)}$. Additionally, intakes of discretionary energy from solid fats and added sugars considerably exceed recommendations ${ }^{(3)}$.

More than 55 million US children aged 5-19 years spend the majority of their day in school ${ }^{(4)}$. Through the federally assisted National School Lunch Program (NSLP) and School Breakfast Program (SBP), schools provide up to two meals and often snacks daily. In 2011, the NSLP served lunch to more than 31 million children each day ${ }^{(5)}$. Students who participate in both the NLSP and SBP may consume up to $47 \%$ of their daily energy intake from school meals/snacks, placing schools in a position to significantly influence children's food choices and diet quality on a daily basis ${ }^{(6)}$.

Under the previous standards for national child nutrition programmes, enacted by the Child Nutrition and WIC Reauthorization Act of 2004 (CNR) ${ }^{(7)}$, school lunches were planned to provide children with one-third of the RDA of protein, $\mathrm{Ca}, \mathrm{Fe}$, and vitamins $\mathrm{A}$ and $\mathrm{C}$ from five required meal components: $2 \mathrm{oz}$ meat/meat alternate, $8 \mathrm{oz}$ milk, 1 serving of grain (whole grains are encouraged) and 2 servings (total of $3 / 4$ cup) of fruit or vegetables ${ }^{(8)}$. 
According to the Third School Nutrition Dietary Assessment Study (SNDA III) ${ }^{(9)}$, over $85 \%$ of US public schools offered lunches that met the standards for these key nutrients. However, fewer than one-third of these schools offered lunches that met the standard of less than $30 \%$ of energy from fat or less than $10 \%$ of energy from saturated fat ${ }^{(10)}$.

Recognizing there were still improvements to be made, in 2009 the Institute of Medicine recommended new meal standards that closely aligned with the Dietary Guidelines for Americans ${ }^{(11)}$. In 2010, national legislation directed the US Department of Agriculture to update school meal regulations and align them with the Institute of Medicine's recommendations ${ }^{(12)}$. The final school meal standards, released in 2012, limit energy and provide minimum and maximum amounts of energy for each age group ${ }^{(13)}$. The standards also require a serving of fruit and a serving of vegetables daily with a weekly requirement for vegetable subgroups (dark green and orange vegetables and legumes). The previous standards required only a fruit or a vegetable and no requirement for vegetable subgroups ${ }^{(8)}$. Students will also be required to take a minimum of a fruit or a vegetable, whereas the previous guidelines allowed them to refuse both, if desired. Fifty per cent of grain foods must be whole grains. The new meal standards should help students improve their dietary intake at school, if the additional components are chosen and consumed. The Offer Versus Serve (OVS) provision of the NSLP meal regulations requires all five components to be made available; however, students are only required to take three of them. This provides students with choice and flexibility but creates a situation where lunches they actually choose and consume may not meet the standards for key nutrients ${ }^{(14)}$.

To implement the new standards, it is important for school nutrition programmes to know what choices students are making and determine how to encourage students to select the additional vegetable and fruit offerings. Therefore, the purpose of the present study was to: (i) evaluate consumption patterns and food choices (via plate waste) of northern Colorado elementaryand middle-school students who participated the NSLP; and (ii) compare students' average nutrient intake from lunch with the 2004 (CNR) lunch standards and the new (Healthy, Hunger-Free Kids Act, HHFKA) school meal standards.

\section{Methods}

\section{Participants}

Students from three elementary schools and two middle schools in one northern Colorado district participated in the present study in autumn of 2010. The district's population of more than 15000 students was $77 \%$ white, 18\% Hispanic, 1.2\% Asian and 0.9\% African American. Approximately $35 \%$ of students were eligible to receive free or reduced-price meals and $49 \%$ of all students ate lunch at school. Average daily school lunch participation was $70 \%$ for elementary schools and $57 \%$ for middle schools. Elementary-school participants were children in grades 1 to 5 and middle-school participants were in grades 6 to 8 .

Up to 185 students at each school were randomly selected using the district's cashiering and account management system (WinSnap version 2.6・4 2010; SLTech, Santa Monica, CA, USA) from those who regularly participate in the NSLP. Use of this database also allowed selection of similar numbers of boys and girls and students in each grade level. Cafeteria managers flagged selected students in the point-of-sale system so that cashiers were alerted when a selected student purchased an NSLP lunch.

At no time were individual students associated with particular lunches and no personal identifying information about students was collected other than gender and grade. No photographs of students were taken as part of this research. The study was conducted according to the guidelines laid down in the Declaration of Helsinki and all procedures involving human subjects/patients were approved by the Colorado State University Institutional Review Board (Fort Collins, CO) and Thompson School District (Loveland, CO).

\section{Procedure}

Elementary and secondary lunch menus for October and November 2010 (the months corresponding to plate waste assessment) were obtained from the district. The district used a 4-week cycle menu. Menus were analysed by district nutrition services staff using Nutrikids menu planning and nutrient analysis software version $12 \cdot 0$ (LunchByte Systems, Inc., Rochester, NY, USA), which provided daily and monthly averages (based on portion values) for energy, protein, fibre, $\mathrm{Na}$, vitamins $\mathrm{A}$ and $\mathrm{C}, \mathrm{Ca}, \mathrm{Fe}$, total and saturated fat. All schools utilized the OVS provision.

\section{Plate waste measurement}

Plate waste measures were conducted over five days in each elementary school and four days in each middle school using a previously validated digital photography method $^{(15-17)}$. A digital camera (Fuji FinePix Z10fd, 7·2 MP with optical zoom, Tokyo, Japan) was mounted on a tripod $66 \mathrm{~cm}$ (26 in) above lunch trays and angled down at approximately $45^{\circ}$. Five servings of each pre-portioned menu item (entrées, fruits, vegetables and breads) were obtained from the cafeteria each day, arranged on trays and photographed. These reference photographs were used for comparison with the post-consumption photographs of each student's tray. After photographing the reference foods, they were packed in a cooler, taken back to a laboratory and weighed on a calibrated digital scale (A\&D, SK-2000D, Seoul, Korea). The average weight of the five portions for each food item was recorded to the nearest $0 \cdot 1 \mathrm{~g}$ and served as the standard when estimating 
the weight of food consumed. Of the 130 food items for which five portions were collected, only eight had a standard deviation greater than $10 \%$ of the mean, indicating little variation between reference samples.

As students walked through the serving line and made their selections, the district's electronic point-of-sale and account management system alerted the lunch cashier if a student had been selected to have his/her tray photographed after consumption. A research assistant obtained verbal assent from the student. On a small index card, pre-printed with the date and lunch menu, a research assistant placed a check mark by the foods selected, recorded gender and grade, and then affixed the card to the student's tray. When students finished eating, they took their trays to the photography station for postconsumption photographs. Trays were placed on a reference board to ensure consistent position of all trays in the camera frame. Prior to taking the post-consumption picture, research assistants re-positioned remaining food items and containers on the trays to ensure all items were visible in the photograph. For example, napkins and utensils were removed and if the student had combined the waste of two or more foods, they were separated if possible. Beverage waste was poured into a liquid measuring cup and ounces remaining were recorded.

Each day of data collection, approximately $20 \%$ of postconsumption student trays were packed and carried back for weighing. The weight of each remaining (uneaten) food item was divided by the average weight of the five reference portions to calculate percentage of food wasted. This number was compared with the result of visual plate waste estimation as a confirmation of observer reliability. There was $92 \%$ agreement between the weighed trays and plate waste estimated visually from post-consumption photographs.

\section{Data analysis}

The percentage of students selecting each menu item was calculated from the frequency and total number of students whose trays were photographed. Percentage waste was estimated for menu items categorized as entrée, canned fruit, fresh fruit, vegetable, grain and milk. The entrée was typically a combination food that included a meat/meat alternate with a grain and/or vegetable. Since it was not possible to separate the individual components, the entrée was evaluated as one item. Canned fruit and fresh fruit were evaluated and reported separately because some students selected both and wasted different amounts of each. Grains were evaluated separately only if they were offered as an individual menu item choice, such as a breadstick or dinner roll.

Two trained analysts simultaneously reviewed the post-consumption photographs alongside the reference food photographs and determined the proportion of each food item wasted to the nearest $10 \%$ increment. Differences in observations greater than $20 \%$ for any food item were resolved by reviewing photographs of similar weighed trays alongside the reference tray photographs and student tray in question. Consensus was reached when estimates from each observer were within $10 \%$ of each other and the average was recorded.

Percentage of each food item wasted was entered into an Excel ${ }^{\circledR}$ spreadsheet and imported into the statistical software package SPSS version $9 \cdot 2$ for Windows. Descriptive statistics (frequency, mean and standard deviation) were calculated for percentage waste of each food item. Univariate ANOVA was conducted to determine differences in percentage plate waste between genders, schools and grades. Differences were determined to be statistically significant at $P \leq 0 \cdot 05$. The percentage of each food item consumed was determined based on the percentage wasted and merged with the school district's nutrient analysis data using the statistical software package SAS version 9.2 for Windows. Average lunch nutrient intake per student for energy, protein, fibre, $\mathrm{Na}$, vitamins $\mathrm{A}$ and $\mathrm{C}, \mathrm{Ca}, \mathrm{Fe}$, total fat and saturated fat was calculated by multiplying the percentage consumed by the nutrient values for each food item. Percentages were used to describe the proportion of students meeting or exceeding the 2004 CNR meal standards ${ }^{(8)}$ and the HHFKA meal guidelines ${ }^{(13)}$. The final HHFKA school meal nutrition recommendations direct districts to use a food-based menu planning approach and recommend specific nutrient targets for energy, percentage of energy from saturated fat and $\mathrm{Na}^{(13)}$. Since the HHFKA final meal standards did not provide nutrient targets for total protein, $\mathrm{Ca}, \mathrm{Fe}$, vitamins $\mathrm{A}$ and $\mathrm{C}$, and dietary fibre, the recommendations from the Institute of Medicine ${ }^{(11)}$ were used.

\section{Results}

The characteristics of the participating schools are provided in Table 1. Elementary schools B (ES B) and C (ES C) had a higher percentage of students who qualified for free and reduced-priced meals than elementary school A (ES A). ES B scheduled recess before lunch for grades 3-5 only and ES C scheduled recess after lunch. All elementary schools provided $20 \mathrm{~min}$ per grade for the students to eat lunch.

The two middle schools (MS A and MS B) had 49\% and $30 \%$ of students who qualified for free and reducedpriced lunches, respectively. They had similar cafeteria layouts, each with three tray lines from which students could purchase lunch. Both schools had limited availability of à la carte items, such as baked chips, small cookies, bottled water and fruit soda. The schools differed in their lunch schedules. MS A had three 30-min lunch periods, one for each grade. MS B had two 30-min lunch periods, with the 7 th grade divided between the lunch periods. 
Table 1 Characteristics of study schools, northern Colorado, USA, autumn 2010

\begin{tabular}{|c|c|c|c|c|c|}
\hline School & $\begin{array}{l}\% \text { Eligible for free/reduced- } \\
\text { priced lunches }\end{array}$ & $\begin{array}{c}\text { NSLP } \\
\text { participation (\%) }\end{array}$ & $\begin{array}{l}\text { Recess before } \\
\text { lunch }\end{array}$ & $\begin{array}{l}\text { À la carte } \\
\text { foods }\end{array}$ & $\begin{array}{l}\text { Lunch length } \\
\text { (min/grade) }\end{array}$ \\
\hline \multicolumn{6}{|c|}{ Elementary schools } \\
\hline A & 35 & 63 & Yes & No & 20 \\
\hline B & 60 & 75 & Grades 3-5 & No & 20 \\
\hline C & 64 & 77 & No & No & 20 \\
\hline \multicolumn{6}{|c|}{ Middle schools } \\
\hline A & 49 & 74 & $\mathrm{~N} / \mathrm{A}$ & Yes & 30 \\
\hline B & 30 & 66 & $\mathrm{~N} / \mathrm{A}$ & Yes & 30 \\
\hline
\end{tabular}

NSLP, National School Lunch Program; N/A, not applicable.

Table 2 Number and percentage of elementary- and middle-school students who selected each menu item, northern Colorado, USA, autumn 2010

\begin{tabular}{|c|c|c|c|c|c|c|c|c|c|c|c|c|c|c|}
\hline & & & & & & & & & \multicolumn{6}{|c|}{ Milk } \\
\hline & \multicolumn{2}{|c|}{ Entrée } & \multicolumn{2}{|c|}{ Canned fruit } & \multicolumn{2}{|c|}{ Fresh fruit } & \multicolumn{2}{|c|}{ Vegetable } & \multicolumn{2}{|c|}{ Total } & \multicolumn{2}{|c|}{ Chocolate $^{*}$} & \multicolumn{2}{|c|}{ Whitet } \\
\hline & $n$ & $\%$ & $n$ & $\%$ & $n$ & $\%$ & $n$ & $\%$ & $n$ & $\%$ & $n$ & $\%$ & $n$ & $\%$ \\
\hline Elementary schools & 535 & 100 & 320 & 59 & 305 & 56 & 243 & 45 & 512 & 96 & 417 & 78 & 95 & 18 \\
\hline Middle schools & 364 & 100 & 189 & 52 & 142 & 39 & 124 & 34 & 297 & 82 & 262 & 72 & 35 & 10 \\
\hline
\end{tabular}

${ }^{*}$ Fat-free chocolate milk.

+White, $1 \%$ fat or fat-free white milk.

A total of 899 students, 535 elementary-school students and 364 middle-school students, participated in the study. Of the elementary-school students, $50 \cdot 5 \%$ were males with $18.9 \%, 20 \cdot 9 \%, 20 \cdot 2 \%, 20 \cdot 4 \%$ and $19 \cdot 6 \%$ from grades 1 to 5 , respectively. Of the middle school students, $53 \cdot 8 \%$ were males with $35 \cdot 2 \%, 32 \cdot 7 \%$ and $32 \cdot 1 \%$ from grades 6 to 8 , respectively.

Various food choices were offered on the district menus. Elementary-school students could choose from three different entrées (one hot option, a deli sandwich or a third cold option, such as an entrée salad), two fruits (one canned and one fresh), a vegetable, and low-fat or fat-free white or fat-free chocolate milk for lunch daily. Middle-school students had a daily choice of four entrées (two hot options, a deli sandwich or an entrée salad), canned and fresh fruit, and hot and fresh vegetables. In both elementary and middle schools, at least half the grain items served were whole grain and often incorporated into the entrée. Low-fat white, fat-free white and fat-free chocolate milk were available daily at middle schools as well. For both elementary- and middle-school menus, the monthly average for energy was below the 2004 CNR meal standards; however, they met or exceeded guidelines for all other nutrient targets (data not shown).

Table 2 shows the number and percentage of students who selected each menu item. While all students chose an entrée, less than half of elementary- and middle-school students selected a vegetable with lunch. Students were more likely to select fruit with lunch. When canned and fresh fruit were combined, some students took both, and therefore more than $60 \%$ took at least one serving of fruit with lunch. Approximately $96 \%$ of elementary-school students and $82 \%$ of middle-school students selected milk with their lunch, of which three-quarters was fat-free chocolate.

The percentage of each menu item wasted is provided by school, grade and gender in Table 3. Elementaryschool students wasted more than one-third of individual grain, canned fruit, fresh fruit and hot and fresh vegetable menu items. Significant differences $(P<0 \cdot 05)$ in the percentage of each menu item wasted were observed between ES A and ES B and ES C. Students from ES A had higher consumption patterns for all menu items when compared with the other two elementary schools. Students in grades 4 and 5 wasted one-third to one-half less of each menu item than students in grades 1 and 2. Males had less waste, and therefore higher consumption, for the entrée, canned fruit, fresh fruit and milk. However, these differences were significant only for the entrée $(P=0 \cdot 001)$ and milk $(P<0 \cdot 0001)$.

Middle-school students left nearly half of fresh fruit, over a third of canned fruit and nearly a third of vegetables unconsumed. Students from MS A wasted significantly less entrée than students from MS B $(P=0 \cdot 041)$. Additionally, there was a difference in vegetable waste between the middle schools; however, due to the low number of students who selected vegetables, this difference was not statistically significant $(P=0 \cdot 19)$. Middle-school students in grade 8 wasted significantly less of the entrée than those in grades $6(P=0 \cdot 001)$ and $7(P=0 \cdot 025)$. There was a significant difference in waste between middle-school males and females for canned fruit $(P=0 \cdot 004)$ and milk $(P=0 \cdot 002)$, with females wasting more than males. Middleschool females also wasted more of individual grain 
Table 3 Percentage waste (least-squared means and their standard errors) of each lunch menu item by school, grade level and gender, northern Colorado, USA, autumn 2010

\begin{tabular}{|c|c|c|c|c|c|c|c|c|c|c|c|c|}
\hline & \multicolumn{12}{|c|}{ Percentage waste } \\
\hline & \multicolumn{2}{|c|}{ Entrée } & \multicolumn{2}{|c|}{ Canned fruit } & \multicolumn{2}{|c|}{ Fresh fruit } & \multicolumn{2}{|c|}{ Vegetable } & \multicolumn{2}{|c|}{ Grain } & \multicolumn{2}{|c|}{ Milk } \\
\hline & Mean & $\mathrm{SE}$ & Mean & $\mathrm{SE}$ & Mean & SE & Mean & $\mathrm{SE}$ & Mean & SE & Mean & SE \\
\hline \multicolumn{13}{|c|}{ Elementary schools } \\
\hline Overall & $23 \cdot 8$ & $1 \cdot 2$ & $37 \cdot 3$ & $2 \cdot 2$ & $37 \cdot 0$ & $2 \cdot 2$ & $33 \cdot 6$ & $2 \cdot 2$ & $44 \cdot 6$ & $2 \cdot 5$ & $32 \cdot 6$ & $1 \cdot 5$ \\
\hline A & $20 \cdot 1^{a}$ & $2 \cdot \overline{1}$ & $29 \cdot 6^{a}$ & $3 . \overline{5}$ & $25 \cdot 2^{a}$ & $3 . \overline{9}$ & $24 \cdot 4^{a}$ & $4 \cdot 2$ & $17 \cdot 6^{a}$ & $4 \cdot 1$ & $18 \cdot 2^{a}$ & $2 \cdot 6$ \\
\hline $\mathrm{B}$ & $26 \cdot 4^{a}$ & $2 \cdot 1$ & $42 \cdot 0^{\mathrm{b}}$ & 3.7 & $43 \cdot 5^{b}$ & $4 \cdot 0$ & $33 \cdot 7^{a, b}$ & $3 \cdot 8$ & $64 \cdot 4^{\mathrm{b}}$ & 4.9 & $33 \cdot 7^{\mathrm{b}}$ & $2 \cdot 5$ \\
\hline $\mathrm{C}$ & $24 \cdot 9^{a, b}$ & $2 \cdot 1$ & $40 \cdot 5^{\mathrm{b}}$ & $4 \cdot 1$ & $42 \cdot 2^{b}$ & $3 \cdot 4$ & $42 \cdot 7^{\mathrm{b}}$ & $3 \cdot 7$ & $51 \cdot 8^{\mathrm{c}}$ & $3 \cdot 8$ & $45 \cdot 9^{c}$ & $2 \cdot 6$ \\
\hline \multicolumn{13}{|l|}{ Grade level } \\
\hline 1 & $35 \cdot 7^{\mathrm{a}}$ & $2 \cdot 8$ & $48 \cdot 2^{a}$ & $4 \cdot 9$ & $51 \cdot 3^{a}$ & $4 \cdot 9$ & $47 \cdot 8^{a}$ & $5 \cdot 5$ & $54 \cdot 7^{\mathrm{a}}$ & $5 \cdot 8$ & $43 \cdot 0^{a}$ & $3 \cdot 4$ \\
\hline 2 & $29 \cdot 4^{a, b}$ & $2 \cdot 6$ & $41 \cdot 7^{\mathrm{a}}$ & $4 \cdot 5$ & $36 \cdot 3^{b}$ & $4 \cdot 5$ & $28 \cdot 4^{\mathrm{b}, \mathrm{c}}$ & 4.9 & $47 \cdot 1^{\mathrm{a}, \mathrm{b}}$ & $5 \cdot 5$ & $40 \cdot 4^{\mathrm{a}}$ & $3 \cdot 3$ \\
\hline 3 & $23 \cdot 5^{\mathrm{b}, \mathrm{c}}$ & $2 \cdot 7$ & $41 \cdot 8^{a}$ & $4 \cdot 7$ & $41 \cdot 4^{\mathrm{a}, \mathrm{b}, \mathrm{c}}$ & $5 \cdot 1$ & $40 \cdot 3^{\mathrm{b}}$ & 4.9 & $47 \cdot 5^{\mathrm{a}, \mathrm{b}}$ & $5 \cdot 2$ & $29 \cdot 3^{\mathrm{b}}$ & $3 \cdot 3$ \\
\hline 4 & $17 \cdot 8^{\mathrm{c}, \mathrm{d}}$ & $2 \cdot 7$ & $26 \cdot 7^{b}$ & $5 \cdot 3$ & $34 \cdot 2^{\mathrm{b}, \mathrm{c}}$ & $4 \cdot 7$ & $35 \cdot 1^{\mathrm{b}}$ & 4.5 & $35 \cdot 0^{\mathrm{b}}$ & $5 \cdot 4$ & $25 \cdot 4^{b}$ & $3 \cdot 2$ \\
\hline 5 & $12 \cdot 6^{\mathrm{d}}$ & $2 \cdot 7$ & $28 \cdot 0^{\mathrm{b}}$ & $4 \cdot 7$ & $21 \cdot 9^{d}$ & 21.9 & $16 \cdot 5^{c}$ & $5 \cdot 1$ & $38 \cdot 7^{\mathrm{b}}$ & $5 \cdot 3$ & $25 \cdot 1^{\mathrm{b}}$ & $3 \cdot 3$ \\
\hline \multicolumn{13}{|l|}{ Gender } \\
\hline Males & $19 \cdot 6^{a}$ & $1 \cdot 7$ & $35 \cdot 1$ & $3 \cdot 1$ & $36 \cdot 6$ & $3 \cdot 0$ & $36 \cdot 1$ & $3 \cdot 2$ & $45 \cdot 6$ & $3 \cdot 4$ & $23 \cdot 8^{a}$ & $2 \cdot 1$ \\
\hline Females & $28 \cdot 0^{\mathrm{b}}$ & $1 \cdot 7$ & 39.5 & 3.0 & $37 \cdot 4$ & $3 \cdot 1$ & $31 \cdot 1$ & $3 \cdot 1$ & $43 \cdot 6$ & $3 \cdot 5$ & $41 \cdot 5^{b}$ & $2 \cdot 1$ \\
\hline \multicolumn{13}{|l|}{ Middle schools } \\
\hline Overall & $19 \cdot 2$ & $1 \cdot 3$ & $37 \cdot 6$ & $2 \cdot 9$ & $47 \cdot 4$ & 3.7 & $30 \cdot 6$ & $3 \cdot 6$ & $20 \cdot 0$ & $2 \cdot 9$ & $21 \cdot 2$ & $1 \cdot 8$ \\
\hline A & $16 \cdot 4^{a}$ & 1.9 & $39 \cdot 4$ & $4 \cdot 1$ & $49 \cdot 4$ & $5 \cdot 5$ & $35 \cdot 7$ & $6 \cdot 3$ & $18 \cdot 7$ & $3 \cdot 8$ & $22 \cdot 1$ & $2 \cdot 1$ \\
\hline B & $21 \cdot 9^{b}$ & 1.9 & $35 \cdot 8$ & $4 \cdot 2$ & $45 \cdot 4$ & $5 \cdot 0$ & $25 \cdot 7$ & $4 \cdot 0$ & $21 \cdot 7$ & $4 \cdot 3$ & $20 \cdot 4$ & $2 \cdot 1$ \\
\hline \multicolumn{13}{|l|}{ Grade level } \\
\hline 6 & $24 \cdot 0^{a}$ & $2 \cdot 3$ & $39 \cdot 3$ & $4 \cdot 8$ & $50 \cdot 2$ & $6 \cdot 4$ & $21 \cdot 5^{a}$ & $6 \cdot 1$ & $16 \cdot 1$ & 4.9 & $22 \cdot 7$ & 2.9 \\
\hline 7 & $20 \cdot 5^{a}$ & $2 \cdot 3$ & $33 \cdot 1$ & $5 \cdot 2$ & $46 \cdot 2$ & $6 \cdot 4$ & $39 \cdot 0^{\mathrm{b}}$ & $6 \cdot 1$ & $18 \cdot 9$ & $5 \cdot 0$ & $17 \cdot 5$ & $3 \cdot 1$ \\
\hline 8 & $13 \cdot 1^{\mathrm{b}}$ & $2 \cdot 3$ & $40 \cdot 3$ & $5 \cdot 1$ & $45 \cdot 8$ & 6.5 & $31 \cdot 6^{\mathrm{a}, \mathrm{b}}$ & $5 \cdot 8$ & $25 \cdot 1$ & $5 \cdot 0$ & $23 \cdot 4$ & $3 \cdot 1$ \\
\hline \multicolumn{13}{|l|}{ Gender } \\
\hline Males & $17 \cdot 0$ & $1 \cdot 8$ & $29 \cdot 0^{\mathrm{a}}$ & $4 \cdot 0$ & $50 \cdot 1$ & $5 \cdot 3$ & $30 \cdot 7$ & $4 \cdot 8$ & 14.5 & $4 \cdot 2$ & $15 \cdot 8^{a}$ & $2 \cdot 3$ \\
\hline Females & $21 \cdot 4$ & $2 \cdot 0$ & $46 \cdot 2^{b}$ & $4 \cdot 3$ & $44 \cdot 7$ & $5 \cdot 2$ & $30 \cdot 7$ & $5 \cdot 0$ & $25 \cdot 5$ & 3.9 & $26 \cdot 6^{\mathrm{b}}$ & $2 \cdot 7$ \\
\hline
\end{tabular}

a,b,c,dMean values within a column with unlike superscript letters were significantly different $(P<0 \cdot 05)$.

foods; the difference trended towards statistical significance $(P=0 \cdot 057)$.

The mean energy intake of elementary-school students was less than both the 2004 CNR and HHFKA guidelines, and therefore very few students met the 2004 CNR or HHFKA targets (Table 4). This result would be expected given that the monthly menu average, based on portion values, was below the energy recommendation. The majority of elementary-school students did not exceed the 2004 CNR and HHFKA recommended intakes for percentage of energy from total fat and saturated fat and nearly two-thirds of students met both recommendations for Ca. However, less than half of elementary-school students met the 2004 CNR or HHFKA recommended nutrient intakes for Fe and vitamins A and C. Very few of these students met the new HHFKA recommendations for fibre and most exceeded the limit for $\mathrm{Na}(640 \mathrm{mg})$.

Similar to elementary-school students, very few middleschool students met the 2004 CNR guidelines for energy intake, although a higher percentage met the HHFKA energy target (Table 5). The majority of middle-school students did not exceed the 2004 CNR and HHFKA recommended intakes for percentage of energy from total fat and saturated fat. With regard to $\mathrm{Ca}$, approximately half of the students met the 2004 CNR recommendation and slightly less than half of the students met the HHFKA guideline. Less than one-third of middle-school students met the 2004 CNR or HHFKA recommended intakes for Fe and vitamins A and C. Very few of these students met the HHFKA recommendations for fibre and average $\mathrm{Na}$ intake exceeded the limit $(710 \mathrm{mg})$.

\section{Discussion}

The amount of plate waste reported in the present study is consistent with amount of waste found in previous studies that examined plate waste in school lunch programmes. Marlette et $a l .{ }^{(18)}$ found an average percentage waste of $44 \%$ for fruit, $24 \%$ for mixed dishes, $15 \%$ for milk and $30 \%$ for vegetables among 6th-grade students. The present study found similar results in middle-school students, which included 6th grade, in which they wasted on average $43 \%$ of fruit (an average of canned and fresh), 19\% of the entrée and $31 \%$ of vegetables. Milk waste was slightly higher in the present study at $21 \%$. However, this represents a difference of less than half an ounce of a standard eight-ounce carton. A 2010 study of 4th-6th grade students in Louisiana reported $37 \%$ wastage of fruits and vegetables combined $^{(5)}$. This compares with overall waste of $37 \%$ of canned fruit, $37 \%$ of fresh fruit and $34 \%$ of vegetables from elementary students in the present study.

The new HHFKA school meal standards are designed to ensure school meals offered to students align with the 
Table 4 USDA NSLP guidelines, mean of school lunch nutrient intake and percentage meeting the 2004 CNR NSLP guidelines and the HHFKA NSLP guidelines among elementary-school students ( $n$ 535), northern Colorado, USA, autumn 2010

\begin{tabular}{|c|c|c|c|c|c|}
\hline Nutrient & $\begin{array}{l}2004 \text { CNR meal } \\
\text { guidelines }^{(8)}\end{array}$ & $\begin{array}{l}\text { HHFKA meal } \\
\text { guidelines }^{(13)}\end{array}$ & $\begin{array}{l}\text { Mean of school } \\
\text { lunch intake }\end{array}$ & $\begin{array}{l}\% \text { Meeting } 2004 \\
\text { CNR guidelines }\end{array}$ & $\begin{array}{c}\% \text { Meeting HHFKA } \\
\text { guidelines }\end{array}$ \\
\hline Energy (kJ) & $2778^{*}$ & $2301-2720 \ddagger \S$ & 1791 & 5 & 11 \\
\hline$\%$ Energy from fat & $<30$ & $<30 \|$ & 27 & 95 & 95 \\
\hline$\%$ Energy from saturated fat & $<10$ & $<10 \S$ & 10 & 87 & 87 \\
\hline Total protein (g) & $>10$ & $>15 \cdot 2 \|$ & 20 & 84 & 72 \\
\hline $\mathrm{Ca}(\mathrm{mg})$ & $>286$ & $>332 \|$ & 378 & 63 & 61 \\
\hline $\mathrm{Fe}(\mathrm{mg})$ & $>3 \cdot 5$ & $>3 \cdot 4 \|$ & $2 \cdot 4$ & 19 & 21 \\
\hline Vitamin A (RE) & $>224$ & $>192 \|$ & 183 & 28 & 31 \\
\hline Vitamin C (mg) & $>15$ & $>24 \|$ & 16 & 43 & 21 \\
\hline Dietary fibre (g) & 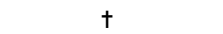 & $>8 \cdot 5 \|$ & $4 \cdot 4$ & $t$ & 8 \\
\hline $\mathrm{Na}(\mathrm{mg})$ & $\dagger$ & $640 \S$ & 785 & + & 10 \\
\hline
\end{tabular}

USDA, US Department of Agriculture; NSLP, National School Lunch Program; CNR, Child Nutrition and WIC Reauthorization Act of 2004; HHFKA, Healthy, Hunger Free Kids Act of 2010; RE, retinol equivalent.

${ }^{*} 664 \mathrm{kcal}$.

†No USDA standard.

$\mp 550-650 \mathrm{kcal}$.

SNutrient targets from the HHFKA final lunch meal pattern.

IINutrient targets from the 2009 Institute of Medicine recommendations ${ }^{(11)}$.

Table 5 USDA NSLP guidelines, mean of school lunch nutrient intake and percentage meeting the 2004 CNR meal guidelines and the HHFKA meal guidelines among middle-school students ( $n$ 364), northern Colorado, USA, autumn 2010

\begin{tabular}{|c|c|c|c|c|c|}
\hline Nutrient & $\begin{array}{l}2004 \mathrm{CNR}_{\text {meal }}^{(8)} \\
\text { guidelines }^{(8)}\end{array}$ & $\begin{array}{l}\text { HHFKA meal } \\
\text { guidelines }^{(13)}\end{array}$ & $\begin{array}{l}\text { Mean of school } \\
\text { lunch intake }\end{array}$ & $\begin{array}{l}\% \text { Meeting } 2004 \\
\text { CNR guidelines }\end{array}$ & $\begin{array}{c}\% \text { Meeting HHFKA } \\
\text { guidelines }\end{array}$ \\
\hline Energy (kJ) & $3452^{*}$ & $2510-2989 \ddagger \S$ & 2223 & 5 & 26 \\
\hline$\%$ Energy from fat & $<30$ & $<30 \|$ & 28 & 88 & 88 \\
\hline$\%$ Energy from saturated fat & $<10$ & $<10 \S$ & $9 \cdot 8$ & 81 & 81 \\
\hline Total protein $(\mathrm{g})$ & $>10$ & $>32 \cdot 211$ & 26 & 84 & 27 \\
\hline $\mathrm{Ca}(\mathrm{mg})$ & $>400$ & $>440 \|$ & 407 & $50 \cdot 1$ & 44 \\
\hline $\mathrm{Fe}(\mathrm{mg})$ & $>4.5$ & $>5 \cdot 2 \|$ & $3 \cdot 1$ & 13 & 7 \\
\hline Vitamin A (RE) & $>300$ & $>241 \|$ & 171 & 15 & 22 \\
\hline Vitamin C (mg) & $>18$ & $>30 \|$ & 15 & 27 & 19 \\
\hline Dietary fibre (g) & $t$ & $>8.6 \|$ & $5 \cdot 8$ & $t$ & 6 \\
\hline $\mathrm{Na}(\mathrm{mg})$ & $t$ & $<710 \S$ & 1089 & $t$ & 22 \\
\hline
\end{tabular}

USDA, US Department of Agriculture; NSLP, National School Lunch Program; CNR, Child Nutrition and WIC Reauthorization Act of 2004; HHFKA, Healthy Hunger Free Kids Act of 2010; RE, retinol equivalent.

*825 kcal.

tNo USDA standard

$\mp 600-700$ kcal.

\$Nutrient targets from the HHFKA final lunch meal pattern.

IINutrient targets from the 2009 Institute of Medicine recommendations ${ }^{(11)}$.

current US Dietary Guidelines for Americans ${ }^{(2)}$, particularly with respect to servings of fruits and vegetables. The new regulations call for an overall increase in the number of fruit and vegetable servings offered to students at lunch, and in the variety of vegetables served each week ${ }^{(13)}$. Also, unlike in the past, students will be required to take a serving of fruit or vegetable with lunch. These provisions should result in students selecting more nutrient-dense lunches. However, results from the present study indicate this may not be the case. While three-quarters of all students chose fruit (canned and fresh combined) with lunch, close to $40 \%$ of these items went uneaten. Of particular concern, less than half of elementary-school students and less than $40 \%$ of middle-school students selected either the hot or fresh vegetables. When students did take a vegetable, more than $30 \%$ went uneaten. This result is in agreement with national data ${ }^{(19)}$ which reported that $96 \%$ of schools offered vegetables; however, only $51 \%$ of students consumed vegetables with lunch. Thirty-eight per cent of those vegetables were categorized as starchy (French fries, white potatoes and corn) and only $6 \%$ of students chose orange or dark green vegetables. A recent study of middleschool students in Texas found that of those students consuming NSLP meals, about $40 \%$ selected and consumed a fruit serving ${ }^{(20)}$. About two-thirds of students selected a vegetable, with only $4 \%$ choosing a dark green or orange vegetable. When students do not consume the fruit and vegetable servings offered with lunch, they are less likely to meet nutrient targets for vitamins A and C, fibre or Fe, as demonstrated by the present study. Therefore, even when school lunch menus are planned to meet the new HHFKA standards, the lunches students choose and consume may not translate into improved dietary intake.

The OVS provision of the NSLP meal regulations was implemented to provide students with choice and minimize plate waste ${ }^{(14)}$. However, the influence of OVS 
on student lunch intake is unclear. A recent study ${ }^{(21)}$ compared fruit and vegetable intake of 4th- and 5th-grade students in a serve-only and an OVS school. All students at the serve-only school took fruit or vegetables with lunch; only $25-72 \%$ of OVS students chose fruit or vegetables. Students at the serve-only school wasted significantly more fruit and vegetables (43-75\%) than students at the OVS school; however, OVS students still wasted $20-44 \%$ of fruits and vegetables selected with lunch. All schools participating in the current study use OVS and student consumption patterns are similar to those from Goggans et $a l^{(21)}$. While OVS may reduce fruit and vegetable plate waste when compared with serveonly, more needs to be done to encourage students to self-select vegetables and encourage their consumption.

Aside from the entrée, the only other menu item selected by more than $80 \%$ of elementary- and middle-school students was milk. Previous studies indicate this likely contributed to more than half of students meeting the $\mathrm{Ca}$ recommendation ${ }^{(22,23)}$. More than $70 \%$ of elementary- and middle-school students who took milk with lunch selected fat-free chocolate milk. Data from SNDA III show most $(60 \%)$ students choose flavoured milk ${ }^{(19)}$. Offering fat-free flavoured milk is a way to help students meet the new meal standards while staying within fat and energy targets ${ }^{(14,24)}$.

Students from ES A did not waste more than $30 \%$ of any menu item and therefore had significantly better consumption of all menu items than students in the other two elementary schools. One possible explanation for the difference is the scheduling of recess before lunch, which has been found to influence the amount of food wasted by elementary-school students ${ }^{(25)}$. A Washington state elementary-school study found food waste decreased from $40 \cdot 1 \%$ to $27 \cdot 2 \%$ when recess was scheduled before lunch $^{(25)}$. As a result, the consumption of most vitamins and minerals was significantly greater when recess occurred before lunch. ES A scheduled recess before lunch for all grades, whereas ES B scheduled recess before lunch only for grades 3-5 and ES C's recess occurred after lunch. While it was not the purpose of the present study to determine the effect of recess scheduling on plate waste, the scheduling of recess before lunch could have had an influence on the reduced plate waste from ES A.

For the first time, the HHFKA meal standards place limits on the amount of $\mathrm{Na}$ in school meals. By 2022, the $\mathrm{Na}$ content of American school lunches must be $53 \%$ lower than the current national average of $1377 \mathrm{mg}$ for elementary school and $1520 \mathrm{mg}$ for middle school ${ }^{(13)}$. $\mathrm{Na}$ reductions will occur incrementally over the next 10 years, with the intent of giving schools and industry the opportunity to work together to lower Na content of school meals. The first incremental reduction takes effect in 2014 with limits of $1230 \mathrm{mg} \mathrm{Na}$ for elementary- and $1360 \mathrm{mg}$ Na for middle-school students ${ }^{(13)}$. While average $\mathrm{Na}$ intake for both elementary and middle schools did not exceed the incremental targets, they did exceed the final
2022 targets of 640 and $710 \mathrm{mg}$, respectively. The Na limitations could have implications for vegetable intake since any seasoning used to increased vegetable consumption will likely be $\mathrm{Na}$ free. Schools will need to be innovative and partner with food industry to create lower Na products and seasonings that are acceptable to students.

Results of the present study identify the need for multifaceted nutrition education and marketing strategies to improve students' self-selection and consumption of vegetables with school lunch. An experiential nutrition education programme combining cooking in the classroom with ongoing cafeteria reinforcement improved students' selection and consumption of fruits and vegetables with school lunch ${ }^{(26)}$. Children's preferences are strongly linked to fruit and vegetable consumption; therefore, behavioural interventions that increase vegetable preference may also increase consumption $^{(27,28)}$. A recent review of behavioural interventions to promote intake of fruits and vegetables reported seven studies conducted in children, with three demonstrating a modest $(0.39$ servings/d) but significant increase in daily fruit and vegetable servings ${ }^{(29)}$. Ageappropriate marketing and communication strategies are another targeted approach for influencing fruit and vegetable consumption ${ }^{(30)}$. Communication campaigns may be effectively combined with behavioural interventions and provide tailored messaging at the school level, targeting intrinsic and extrinsic motivation to increase fruit and vegetable intake with school lunch ${ }^{(29)}$. A small number of studies indicate that the use of behavioural economic strategies in the school cafeteria, such as food location, lighting, verbal prompts and convenience lines, may promote increased fruit and vegetable intake ${ }^{(31,32)}$. These strategies used in conjunction with traditional behavioural interventions and communication strategies may help achieve and sustain children's fruit and vegetable intake at recommended levels.

\section{Study strengths and limitations}

Plate waste assessment of student lunch intake is one of the present study's strengths. Plate waste methodology overcomes the need to rely on students' memory or lack of ability to accurately estimate portion sizes; common limitations of using $24 \mathrm{~h}$ recall with children ${ }^{(33,34)}$. The digital photography method used in the study has been validated by several previous studies as an accurate and convenient method to assess plate waste ${ }^{(5,15-17)}$. There was little disruption to usual lunch service, minimizing an unintended influence on plate waste. Lastly, the study provided the school district with valuable information that will help develop further improvements to the school lunch programme.

There are several limitations that should be noted. The study was conducted in three elementary schools and two middle schools in northern Colorado with primarily white, moderate-income students, limiting generalizability. Also, plate waste was not assessed simultaneously in all schools; 
therefore, differences in the daily menu may have affected the difference in waste between schools.

\section{Conclusions}

The key finding from the present study is that elementaryand middle-school students are not regularly selecting fruit, and particularly vegetables, offered for school lunch. As a result, their lunch consumption does not meet the new national meal standards for vegetable intake and they are falling short of key nutrients including vitamins A and C. As schools implement the provisions of the new national meal standards, they will need to employ several complementary strategies such as nutrition education, marketing communications and behavioural economics to ensure students make the most healthful lunch choices.

\section{Acknowledgements}

Sources of funding: This project was supported by member grant from the Coalition for Activity and Nutrition to Defeat Obesity (CanDo) of Fort Collins, Colorado. CanDo had no role in the design, analysis, or writing of this article. Conflicts of interest: The authors have no conflict of interests to report. Authors' contributions: S.L.S. designed and conducted the study, wrote the manuscript and is the corresponding author. L.C.-S. assisted with project development and co-wrote the manuscript. Acknowledgements: The authors would like to thank Tammie Rempe, Shannon Emslie and Carla Bankes of Thompson School District for their critical guidance and support. They also thank Garry Auld for assistance with the research design and manuscript review and Jim Zumbrunnen for statistical analysis and interpretation.

\section{References}

1. Briggs M, Mueller CG, Fleischhacker S et al. (2010) Position of the American Dietetic Association, School Nutrition Association, and Society for Nutrition Education: comprehensive school nutrition services. J Am Diet Assoc 110, 1738-1749.

2. US Department of Health and Human Services \& US Department of Agriculture (2010) Dietary Guidelines for Americans, 7th ed. Washington, DC: US Government Printing Office.

3. American Dietetic Association (2008) Position of the American Dietetic Association: nutrition guidance for healthy children ages 2 to 11 years. J Am Diet Assoc 108, 1038-1047.

4. US Department of Education, National Center for Education Statistics (2011) Enrollment Trends. http://nces.ed.gov/ fastfacts/display.asp?id=65 (accessed September 2012).

5. Food and Nutrition Service, US Department of Agriculture (2011) National School Lunch Program Fact Sheet. Alexandria, VA: FNS/USDA; available at http://www.fns.usda. gov/cnd/lunch/AboutLunch/NSLPFactSheet.pdf

6. Briefel RR, Crepinsek MK, Cabili C et al. (2009) School food environments and practices affect dietary behaviors of US public school children. J Am Diet Assoc 109, 2 Suppl., S91-S107.
7. Child Nutrition and WIC Reauthorization Act of 2004, Public Law 108-265, Sect. 118 Stat. 731 (June 30, 2004). http://www.gpo.gov/fdsys/pkg/STATUTE-118/pdf/STATUTE118-Pg729.pdf (accessed May 2013).

8. Food and Nutrition Service, US Department of Agriculture (2000) Menu Planning in the National School Lunch Program. Alexandria, VA: FNS/USDA; available at http:// www.fns.usda.gov/cnd/menu/menu_planning.doc

9. Food and Nutrition Service, US Department of Agriculture (2007) School Nutrition Dietary Assessment Study-III: Summary of Findings. Alexandria, VA: FNS/USDA, Office of Research, Nutrition, and Analysis; available at http:// www.fns.usda.gov/ora/menu/published/CNP/FILES/SNDAIIISummaryofFindings.pdf

10. Crepinsek MK, Gordon AR, McKinney PM et al. (2009) Meals offered and served in US public schools: do they meet nutrient standards? J Am Diet Assoc 109, 2 Suppl., S31-S43.

11. Committee on Nutrition Standards for National School Lunch and School Breakfast Programs, Food and Nutrition Board, Institute of Medicine (2010) School Meals: Building Blocks for Healthy Children. Washington, DC: National Academies Press.

12. Healthy, Hunger-Free Kids Act of 2010, Public Law 111296, Sect. 124 Stat. 3183 (December 13, 2010). http:// www.gpo.gov/fdsys/pkg/PLAW-111publ296/pdf/PLAW-111 publ296.pdf (accessed May 2013).

13. Food and Nutrition Service, US Department of Agriculture (2012) Nutrition standards in the National School Lunch and school breakfast programs. Final rule. Fed Regist 77, 4088-4167.

14. Food and Nutrition Service, US Department of Agriculture. (2013) Offer versus Serve: Guidance for the National School Lunch Program and the School Breakfast Program. Alexandria, VA: FNS/USDA; available at http://www.fns.usda.gov/cnd/ governance/Policy-Memos/2013/SP45-2013a.pdf

15. Martin CK, Newton RL Jr, Anton SD et al. (2007) Measurement of children's food intake with digital photography and the effects of second servings upon food intake. Eat Behav 8, 148-156.

16. Williamson DA, Allen R, Martin PD et al. (2003) Comparison of digital photography to weighed and visual estimation of portion sizes. J Am Diet Assoc 103, 1139-1145.

17. Swanson M (2008) Digital photography as a tool to measure school cafeteria consumption. J Sch Health $\mathbf{7 8}$, 432-437.

18. Marlette MA, Templeton SB \& Panemangalore M (2005) Food type, food preparation, and competitive food purchases impact school lunch plate waste by sixth-grade students. J Am Diet Assoc 105, 1779-1782.

19. Condon EM, Crepinsek MK \& Fox MK (2009) School meals: types of foods offered to and consumed by children at lunch and breakfast. J Am Diet Assoc 109, 2 Suppl., S67-S78.

20. Cullen KW, Watson KB \& Dave JM (2011) Middle-school students' school lunch consumption does not meet the new Institute of Medicine's National School Lunch Program recommendations. Public Health Nutr 14, 1876-1881.

21. Goggans M, Lambert L \& Chang Y (2011) Offer versus serve or serve only: does service method affect elementary children's fruit and vegetable consumption? J Child Nutr Manage 35, issue 2; available at http://www.schoolnutrition. org/Content.aspx?id $=16358$

22. Johnson RK, Panely C \& Wang MQ (1998) The association between noon beverage consumption and the diet quality of school-age children. J Child Nutr Manage 22, 95-100.

23. Ballew C, Kuester S \& Gillespie C (2000) Beverage choices affect adequacy of children's nutrient intakes. Arch Pediatr Adolesc Med 154, 1148-1152. 
24. Krueger RA \& Casey MA (2009) Focus Groups: A Practical Guide for Applied Research. Thousand Oaks, CA: SAGE Publications, Inc.

25. Smith SL \& Cunningham-Sabo L (2011) Eat Well to Excel: Report to the Coalition of Activity and Nutrition to Defeat Obesity. Fort Collins, CO: Colorado State University.

26. Liquori T, Koch PD, Contento IR et al. (1998) The cookshop program: outcome evaluation of a nutrition education program linking lunchroom food experiences with classroom cooking experiences. J Nutr Educ 30 302-313.

27. Wojcicki JM \& Heyman MB (2006) Healthier choices and increased participation in a Middle School Lunch Program: effects of nutrition policy changes in San Francisco. $A m J$ Public Health 96, 1542-1547.

28. Blanchette L \& Brug J (2005) Determinants of fruit and vegetable consumption among 6-12-year-old children and effective interventions to increase consumption. J Hum Nutr Diet 18, 431-443.
29. Thomson CA \& Ravia J (2011) A systematic review of behavioral interventions to promote intake of fruit and vegetables. J Am Diet Assoc 111, 1523-1535.

30. Snyder LB (2007) Health communication campaigns and their impact on behavior. J Nutr Educ Behav 39, 2 Suppl., S32-S40.

31. Schwartz MB (2007) The influence of a verbal prompt on school lunch fruit consumption: a pilot study. Int J Behav Nutr Phys Act 4, 6.

32. Fulkerson JA, French SA, Story M et al. (2004) Promotions to increase lower-fat food choices among students in secondary schools: description and outcomes of TACOS (Trying Alternative Cafeteria Options in Schools). Public Health Nutr 7, 665-674.

33. Livingstone MBE, Robson PJ \& Wallace JMW (2004) Issues in dietary intake assessment of children and adolescents. $\mathrm{Br}$ J Nutr 92, Suppl. 2, S213-SS22.

34. Warren JM, Henry CJK, Livingstone MBE et al. (2003) How well do children aged 5-7 years recall food eaten at school lunch? Public Health Nutr 6, 41-47. 